\title{
MOLECULAR DETECTION OF BORRELIA SP. IN ORNITHODOROS SAVIGNYI AND RHIPICEPHALUS ANNULATUS BY FIaB GENE AND BABESIA BIGEMINA IN R. ANNULATUS BY 18S rRNA GENE
}

\author{
By
}

\author{
MOSTAFA I. HASSAN ${ }^{1}$, HANAN S. M. GABR ${ }^{2}$, SOBHY ABDEL-SHAFY ${ }^{3}$, \\ KOTB M. HAMMAD ${ }^{1}$ AND MOSTAFA M. MOKHTAR ${ }^{1^{*}}$
}

Department of Zoology and Entomology ${ }^{1}$, Faculty of Science, Al-Azhar University, Nasr City, Cairo, Department of Zoology and Agricultural Nematology, , Faculty of Agriculture, Cairo University, Giza, and Department of Parasitology and Animal Diseas$\mathrm{es}^{3}$, Veterinary Research Division, National Research Centre, Dokki, Giza, Egypt ( ${ }^{*}$ Correspondence:drmosta80@gmail.com)

\section{Abstract}

This study determined the ability of the soft tick, Ornithodoros savignyi and the hard tick, Rhipicephalus (formerly Boophilus) annulatus to serve as carrier for new genotypes of Borrelia and Babesia. Ornithodoros savignyi, was collected in the summer, 2015 from camel market at Shalatein, Red Sea Governorate, while $R$. annulatus was collected from cows at Salhia, Sharkia Governorate and Banha, Qalyoubia Governorate. Hemolymph smears were prepared and stained with Giemsa stain and examined by light microscope (LM) for the presence of spiral form of Borrelia and vermicule stage of Babesia. The tick specimens that revealed positive infection with either Borrelia or Babesia by LM were screened by PCR using flaB gene for Borrelia and $18 S$ rRNA gene for Babesia. The obtained amplicons were sequenced, registered in GenBank and the phylogenetic trees for the obtained sequences were constructed. Results showed that spirochetes (Borrelia) were found in $O$. savignyi and $R$. annulatus, while the vermicule form of Babesia was found in $R$. annulatus only. The PCR amplified Borrelia and Babesia at $350 \& 50 \mathrm{bp}$, respectively. The obtained amplicons were recorded in GenBank with accession number MF084762, MF084761 \& MF004418 for Borrelia sp. in O. savignyi, Borrelia sp. in $R$. annula-tus and B. bigemina in $R$. annulatus, respectively. The genotype of Borrelia sp. recorded in $O$. savignyi is very close to B. burgdroferi that causes Lyme disease in human. But, genotype of Borrelia sp. recorded in $R$. annulatus is close to $B$. theileri that causes a mild disease in animals. Genotype of Babesia in R. annulatus was $100 \%$ identical with B. bigemina that recorded before.

Keywords: FlaB, 18S rRNA, Borrelia, Babesia, Ornithodoros savignyi, Rhipicephalus annulatus.

\section{Introduction}

Persons and animals that become ill after a tick bite may be at increased risk because a tick bite may be considered as the source of the pathogen. Detailed knowledge of the causative agents, their distribution, and their relationship to potential vectors is also lacking (Williamson et al, 2010). In humans, Lyme Borreliosis occurs in all age groups, with equal prevalence in men and women which become infected from the bite of an infected tick (Adham et al, 2010). The clinical signs and symptoms of infection in cattle and other animals are mild and variable, but usually include fever and anemia (McCoy et $a l$, 2014).The disease usually begins with a characteristic skin lesion, erythema migrans at the site of the tick bite. After several days or weeks, the spirochetes typically spread hematogenously, and patients may develop early-disseminated disease with dermatologic, cardiac, neurologic, and rheuma-tologic involvement. Late-stage disease can present chiefly as arthritis and/or neurological impairment (Steere et al, 1977; Elhelw et al, 2014). The tick-borne Relapsing fever endemic commonly transmitted by argasid soft ticks with the exception of Borrelia sp., transmitted by several species of Ixodes hard ticks (Parola et al, 2001; Krause et al, 2015). In Africa, relapsing fever borreliae cause mild to fatal septicemia and termination (El Bahnasawy et al, 2012). The genus Borrelia is composed of bacterial pathogens responsible for relapsing fever and Lyme borreliosis (Haitham et al, 2013). While the Lyme disease agent Borrelia sp. (Casjens et al, 2000) was transmitted by hard ticks, the re- 
lapsing fever borreliae are transmitted by soft ticks (Vial et al, 2006; Trape et al, 2013). In Egypt, available data about the incidence and prevalence of Lyme disease are few (Haberberger et al, 1989). Only three recent studies have pointed out Lyme borreliosis (Elhelw et al, 2014), the molecular evidence of B. burgdorferi in ticks (Adham et $a l, 2010)$ and serological screening of Lyme disease in children (Hammoud et al, 1995). No studies documented the presence of Lyme borreliosis in Egyptian animals, but only in man (El Bahanasay et al, 2015). Borreliosis, is caused by the spirochete, Borrelia theileri transmitted by bite of an infected ticks of the subgenus Rhipicephalus (formerly Boophilus): Rhipicephalus annulatus, $R$. hipicephalus microplus, $R$. hipicephalus decoloratus, and $R$. hipicephalus geigyi. The mitochondrial 12S rRNA and 16S rRNA genes from selected ticks, and the Borrelia flaB, and $16 \mathrm{~S}$ rRNA genes were PCRamplified and sequenced (McCoy et al, 2014) A high infection rate $(66 \%)$ of $B$. burgdorferi was observed in both nymph and adult soft ticks $O$. savignyi used OspC gene in PCR amplified (Adham et al, 2010). The identification of the $B$. orrelia persica with its vector Ornithodoros tholozani used sequences of different genes such as $16 \mathrm{~S}$ rRNA, 12S rRNA, flaB, 18S rRNA and glpQ (Safdie et al, 2010).

Babesia is an apicomplexan hemoparasite transmitted by ticks to a wide variety of mammalian hosts and cause significant mortality and morbidity to them. (El-Fayomy et $a l$, 2013). In Egypt, zoonotic babesiosis was reported in man and dogs (Saleh et al, 2015). Babesiosis have long been recognized as economically important disease of cattle because they cause extensive erythrocytic lysis leading to anemia, icterus, fever, hemoglobinuria and death in not early treated cases (Vial and Gorenflot, 2006). Babesia bigemina was molecularly identified by using 18S rRNA gene in Uganda (Byaruhanga et al, 2016). It was detected by the same gene in Egypt (Elhaig et al, 2016). The first attempt to determine the prevalence of $B . b i$ gemina in Boophilus annulatus used 18 rRNA gene sequences in Egypt (Adham et $a l, 2009)$. The detection and specific discrimination of Babesia sp. and Borrelia sp. in ticks is of risky importance. Microscopic techniques for haemolymph examination remain the most appropriate for the diagnosis of acute disease (Almeria et al, 2001). Meanwhile, the main drawbacks for the microscopic detection of Babesia spp. and Borrelia spp. in haemolymph of ticks are the low sensitivity and the difficulty of differentiating between the species involved (Guglielmone et al, 1997). Polymerase chain reaction (PCR)-based detection methods were described that proved to be extremely sensitive and specific in the detection of Babesia and Borrelia organisms (Smeenk et al, 2000; Almeria et al, 2001).

This study was designed to determine ability of the commonest soft tick, $O$. savignyi that infest camels and the hard tick, R. annulatus that infest cows to serve as carriers for new genotypes of Borrelia in O. savignyi and $R$. annulatus as well as Babesia in $R$. annulatus.

\section{Materials and methods}

Tick collection: Soft tick Ornithodoros savignyi was collected from camel's body during summer 2015 from Shalatein, Red Sea

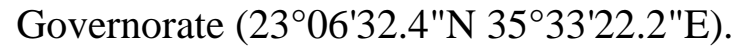

However, the hard tick Rhipicephalus (formerly Boophilus) annulatus was collected from the body of cows and their pens, during the same season from Salhia, Sharkia Governorate $\left(30^{\circ} 49^{\prime} 29.3^{\prime \prime N} \quad 32^{\circ} 04^{\prime} 00.3^{\prime \prime} \mathrm{E}\right)$ and Banha, Qalyoubia Governorate $\left(30^{\circ} 25^{\prime}\right.$ $\left.57.3^{\prime \prime} \mathrm{N} 31^{\circ} 12^{\prime} 34.1^{\prime \prime E}\right)$. The tick specimens were brought alive to the laboratory of Animal Acarines Research Center, Faculty of Agriculture, Cairo University. The collected ticks were maintained alive at $28 \pm 1^{\circ} \mathrm{C}$ and $75 \pm 5 \%$ relative humidity for further procedures. Locality (using Global Positioning System G.P.S.), host, date, climatic condition (temperature and relative humidity), and position of infestation of the ticks collected 
were recorded. The identification of ticks was performed in the laboratory using the taxonomic keys (Hoogstraal, 1956; Walker et al, 2003).

Tick hemolymph smear preparation: Hemolymph was obtained from each tick by amputating the distal portion of one or more legs and smeared on microscopic slide (Burgdorfer, 1970). The hemolymph slides were dried in air and stained with Giemsa to investigate the presence of Borrelia in haemolymph slides prepared from $O$. savignyi and $R$. annulatus or Babesia from smears prepared from $R$. annulatus only. The prepared hemolymph slides were examined under oil emersion lens using ordinary microscope (Zeiss). The tick specimens that revealed positive infection with Borrelia or Babesia by light microscope were stored at $20^{\circ} \mathrm{C}$ for molecular biology procedures.

DNA Extraction: The DNA of tick specimens that revealed positive infection with either Borrelia or Babesia was extracted. The frozen ticks were cut into small pieces using a disposable scalpel in $1.5 \mu \mathrm{L}$ Eppendorf tubes under a sterile laminar flow hood in Molecular Biology Laboratory, Zoology department, Faculty of Science, Menoufia University. The DNA was extracted from the ticks used the PureLink ${ }^{\circledR}$ Genomic DNA Kits (Invitrogen, USA). Briefly, each sample was covered in the tissue lysis buffer included in the kit (between $180 \mu \mathrm{L} \& 540 \mu \mathrm{L}$ depending on the size of tick) and treated with proteinase $\mathrm{K}(20 \mu \mathrm{L} / 180 \mu \mathrm{L}$ of tissue lysis buffer) incubated to 48 hat $56^{\circ} \mathrm{C}$. Subsequent steps were carried out according to the manufacturer's instructions (Invitrogen, USA).

Polymerase chain reaction (PCR): PCR amplification was performed in a final reaction volume $2 \mathrm{X}(50 \mu \mathrm{L})$ containing $25 \mu \mathrm{L} 2 \mathrm{X}$ master mix solution $\left(i-\mathrm{Taq}^{\mathrm{TM}}\right.$, iNtRON, Korea), $0.2 \mathrm{uM}(2 \mu \mathrm{L})$ of each primer, $4 \mu \mathrm{L}$ template DNA, $2.5 \mu \mathrm{L}$ Bovine serum albumin, and $14.5 \mu \mathrm{L}$ nuclease-free water. The designated primers were obtained from Macrogen, Korea. The oligonucleotide sequences of the used primers were listed (Tab.1). The PCR conditions of Borrelia were: an initial denaturation at $95^{\circ} \mathrm{C}$ for $7 \mathrm{~min}$ followed by 40 cycles of denaturation at $95^{\circ} \mathrm{C}$ for $1 \mathrm{~min}$, annealing at $55^{\circ} \mathrm{C}$ for $1 \mathrm{~min}$, and extension at $72^{\circ} \mathrm{C}$ for $1 \mathrm{~min}$, followed by final extension at $72^{\circ} \mathrm{C}$ for $10 \mathrm{~min}$. The PCR conditions of Babesia were: an initial denaturation at $94^{\circ} \mathrm{C}$ for $10 \mathrm{~min}$ followed by 45 cycles of denaturation at $94^{\circ} \mathrm{C}$ for $1 \mathrm{~min}$, annealing at $61^{\circ} \mathrm{C}$ for $1 \mathrm{~min}$, and extension at $72^{\circ} \mathrm{C}$ for $1 \mathrm{~min}$, followed by final extension at $72^{\circ} \mathrm{C}$ for $10 \mathrm{~min}$. The amplification reactions were carried out in a PCR thermal cycler Biometra T-personal/Germany $\mathrm{S} / \mathrm{N}$ 1003507 and the corresponding amplicons were checked on $1 \%$ agarose gel using TAE buffer, stained with ethidium bromide, examined under UV transilluminator, and photographed using a digital camera.

Table 1: Nucleotide sequence of primer used for PCR of tick specimens

\begin{tabular}{|c|c|c|c|c|}
\hline Region DNA & Primer's sequence $\left(5^{\prime} \rightarrow 3^{\prime}\right)$ & Specificity & Annealing Tep./ PCR product & Reference \\
\hline FlaB & 5'- AACAGCTGAAGAGCTTGGAATG -3' & Borrelia sp. & $55^{\circ} \mathrm{C} / 350 \mathrm{bp}$ & Williamson et al, 2010 \\
\hline FlaB & 5'- CTTTGATCACTTATCATTCTAATAGC -3' & & & \\
\hline $18 S r R N A$ & 5'- GTTTCTGMCCCATCAGCTTGAC -3' & Babesia sp. & $61^{\circ} \mathrm{C} / 450 \mathrm{bp}$ & Hilpertshauser et al, 2006 \\
\hline $18 S$ rRNA & 5'- CAAGACAAAAGTCTGCTTGAAAC -3' & & & \\
\hline
\end{tabular}

Sequence analysis and construction of phylogenetic trees: Reaction products that contained an amplified fragment were purified using a GenElute PCR Clean-Up Kit (Sigma, Germany). The DNA sequencing was performed on one strand using the same primers employed for PCR. Sequences of Borrelia FlaB and Babesia18S rRNA, amplicons were aligned. The obtained sequences were assembled using Chromas Pro 1.5 beta (Technelysium Pty. Ltd., Tewantin, QLD, Australia). The resulting sequences were then subjected to Basic Local Alignment Search Tool (BLAST) analysis to determine similarities with those sequences available in the GenBank database hosted by the National Center for Biotechnology Information (NCBI). Phylogenetic relationships between new Egyptian isolates and other reference strains published in Gen- 
Bank were inferred using the BioEdit sequence alignment editor (v. 7.2.6.). Two phylogenetic trees were constructed with the neighbor joining method (NJ) (Saitou and Nei, 1987). Phylogenetic analyses were con- ducted inMEGA5 (Tamura et al, 2007). Different approaches were evaluated in order to identify clades supported by the highest possible bootstrap values. Details are given in tables $(1,2,3,4 \& 5)$.

Table 2: The accession number for sequences used for comparative analysis to Borrelia, obtained from GenBank.

\begin{tabular}{|c|c|c|c|c|}
\hline Accession No. & Species & Country & Host & Reference \\
\hline MF084762 & Borrelia sp. & Egypt & Ornithodoros savignyi & This study \\
\hline MF084761 & Borrelia sp. & Egypt & Rhipicephalus annulatus & This study \\
\hline EF141022.1 & Borrelia sp. & Barazil & Rhipicephalus microplus & Yparraguirre,L.A. \\
\hline KF569936.1 & Borrelia theileri & Mali & Rhipicephalus geigyi & Mccoy,B.N. \\
\hline KP191621.1 & Borrelia theileri & Israel & Ornithodoros sp. & Kleinerman,G. \\
\hline DQ100451.1 & Borrelia lonestari & USA & Carios capensis & Reeves,W.K. \\
\hline AY166716.1 & Borrelia lonestari & USA & Amblyomma americanum & Bacon,R.M. \\
\hline KR677091.1 & Borrelia sp. & Portugal & Hard ticks & Nunes,M. \\
\hline KU933526.1 & Borrelia sp. & USA & Amblyomma americanum & Sayler,K.A. \\
\hline KR677086.1 & Borrelia sp. & Portugal & Hard ticks & Nunes,M. \\
\hline KU749378.1 & Borrelia miyamotoi & China & Human & Jiang, B. G. \\
\hline DQ016626.1 & Borrelia sp. & Poland & Ixodes ricinus & Wodecka,B. \\
\hline AF529084.1 & Borrelia sp. & France & Ixodes ricinus & Richter,D. \\
\hline KR677089.1 & Borrelia sp. & Portugal & Hard ticks & Nunes,M. \\
\hline AY850064.1 & Borrelia lonestari & USA & Amblyomma americanum & Pilgard,M.A. \\
\hline KF894066.1 & Borrelia afzelii & Poland & Mouse & Hildebrand,J. \\
\hline JX257051.1 & Borrelia hispanica & Morocco & Ornithodoros erraticus & Diatta,G. \\
\hline D43777.1 & Borrelia miyamotoi & Japan & Mammals & Fukunaga,M. \\
\hline AY442142.1 & Borrelia lonestari & USA & Amblyomma americanum & Varela,A.S. \\
\hline KT592278.1 & Borreliellaburgdorferi & USA & Lab mice & Esteve-Gassent,M.D. \\
\hline AF007122.1 & Vibrio cholerae & USA & Human & Klose,K.E. \\
\hline EU979630.1 & Borrelia garinii & Russia & Ixodes persulcatus & Beklemishev,A.B. \\
\hline KX444534.1 & Borrelia theileri & Congo & Lice & Amanzougaghene, $\mathrm{N}$. \\
\hline AY552536.1 & Borrelia lonestari & USA & Amblyomma americanum & Varela,A.S. \\
\hline KM875675.1 & Borrelia burgdorferi & USA & Ixodes scapularis & Esteve-Gassent,M.D. \\
\hline AB178780.1 & Borrelia afzelii & Russia & Mouse & Masuzawa,T. \\
\hline Tick species & Hosts & Stages* & Area & Total \\
\hline
\end{tabular}

Table 3: Accession number for sequences used for comparative analysis to Babesia,obtained from GenBank.

\begin{tabular}{|l|l|l|l|l|}
\hline Accession No. & Species & Country & Host & Reference \\
\hline MF004418 & Babesia sp. & Egypt & R. annulatus & This study \\
\hline EF458206.1 & Babesia bigemina & Islands & Cattle & Vogl,S.J. \\
\hline EF458205.1 & Babesia bigemina & Puerto Rico & Cattle & Vogl,S.J. \\
\hline DQ785311.1 & Babesia bigemina & Spain & Cattle & Buling,A. \\
\hline KU206296.1 & Babesia bigemina & Uganda & Cattle & Byaruhanga,C. \\
\hline LC125457.1 & Babesia ovata & Japan & Cattle & Yokoyama,N. \\
\hline FJ869902.1 & Babesia bigemina & Mozambique & Cattle & Martins,T.M. \\
\hline LC125456.1 & Babesia sp. & Vietnam & Cattle & Yokoyama,N. \\
\hline JQ993419.2 & Babesia bigemina & China & Ixodes persulcatus & Zhang,Y. \\
\hline HQ197740.1 & Babesia bigemina & Turkey & Cattle & Inci,A. \\
\hline KF429798.1 & Theileria annulata & Iran & Cell line & Afshari,A. \\
\hline
\end{tabular}

\section{Results}

Total number of soft and hard ticks collected from different localities was 828 ticks (611 O. savignyi\& $215 R$. annulatus).O. savignyi was collected from the camel mar ket's ground at Shalatein, Red Sea Governorate (Tab. 4). But, cattle tick $R$. annulatus was collected from two localities; 172 ticks from Salhia, Sharkia Governorate \&43 ticks from Banha, Qalyoubia Governorate.

Table 4: Tick species collected from host animals in all regions studied

\begin{tabular}{|l|l|l|l|l|l|l|l|}
\hline Tick species & Hosts & Stages * & Shalatein & Birqash & Salhia & Banha & Total \\
\hline O. savignyi & Off host & (M. \& F.) & 611 & - & - & - & 611 \\
\hline R. annulatus & Cows & (M. \& F.) & - & - & 172 & 43 & 215 \\
\hline Total & & & 611 & - & 172 & 43 & 828 \\
\hline
\end{tabular}

*M= Male \& F= Female

Morphological detection of Borrelia and Babesia in tick hemolymph: The positive hemolymph smear with Borrelia was identified by the presence of spiral form of Borre- 
lia (Fig. 1 A-C). Where, the positive haemolymph smear with Babesia was recognized by the presence of identical form of Babesia that called vermicule stage (Fig. 1 D). Percentages of infection with Borrelia and Babesia in the hemolymph smears prepared from $O$. savignyi and $R$. annulatus. A total of 828 ticks (611 O. savignyi and $215 R$. annulatus) were investigated for the presence of Borrelia or Babesia in their hemolymph
(Tab. 5). The overall infection with Borrelia and Babesia was $1.93 \%$ and $0.24 \%$ respectively. Borrelia was recorded in the two tested tick species with the infection rate $0.98 \%$ and $4.65 \%$ in $O$. savignyi and $R$. annulatus, respectively. Ornithodoros savignyi was free from Babesia infection, while only $2 R$. annulatus ticks $(0.93 \%)$ were positive with Babesia.

Table 5: Infection\% of Borrelia and Babesia in smears and PCR prepared from O. savignyi and R. annulatus.

\begin{tabular}{|l|l|l|l|l|l|l|}
\hline Tick species & & No. of ticks & \multicolumn{3}{l|}{ Borrelia sp. (\%) } & \multicolumn{2}{l|}{ Babesia sp. (\%) } \\
\hline & & & Hemolymph. & PCR & Hemolymph. & PCR \\
\hline O. savignyi & Shalatein & 611 & $6(1)$ & $6(1)$ & - & - \\
\hline \multirow{2}{*}{ R. annulatus } & Salhia & 172 & $10(5.8)$ & $10(5.8)$ & $2(1.16)$ & $2(1.16)$ \\
\cline { 2 - 7 } & Banha & 43 & - & - & - & - \\
\hline Total & & 828 & $16(1.93)$ & $16(1.93)$ & $2(0.24)$ & 2 \\
\hline
\end{tabular}

Molecular detection of Borrelia and Babesia in tick tissues: PCR successfully amplified a single $\sim 350 \mathrm{bp}$ fragment of Borrelia $s p$. in $O$. savignyi and $R$. annulatus. PCR successfully amplified a single $\sim 450$ bp fragment of Babesia sp.in R. annulatus (Fig 2).

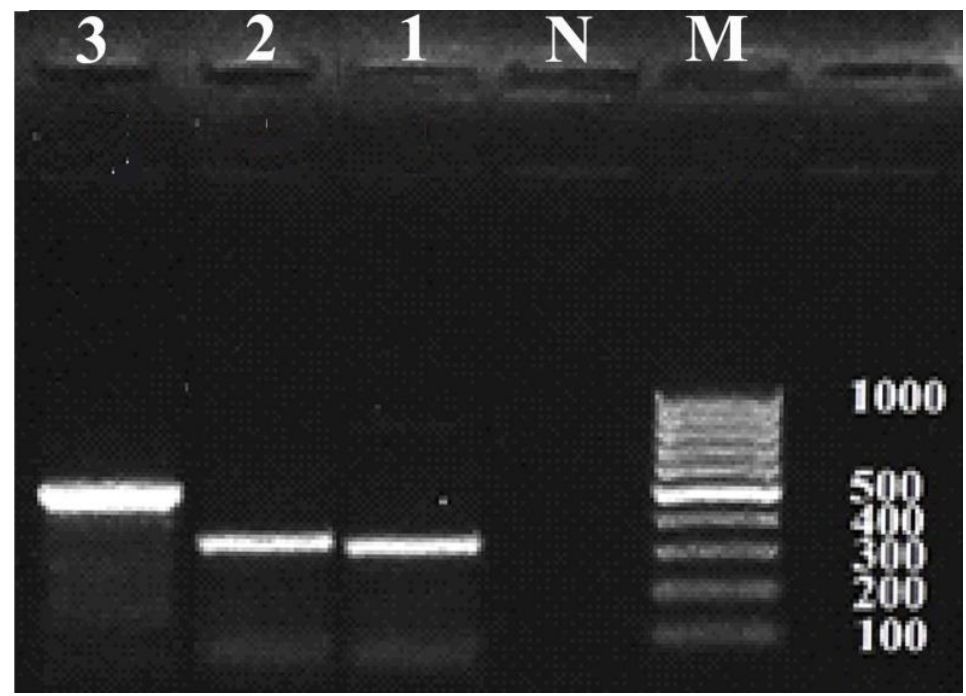

Fig. 2: Agarose gel electrophoresis (1 \%agarose, stained with ethidium bromide): analysis of PCR amplification for detection of Borrelia sp. and Babesia sp. M: 100 bp DNA marker; N: negative control; 1) positive tick sample with Borrelia sp. from O. savignyi at 350 bp; 2) positive tick sample with Borrelia sp. from R. annulatus at $350 \mathrm{bp}$; and 3) positive tick sample with Babesia sp. from R. annulatus at $450 \mathrm{bp}$.

Nucleotide sequencing and phylogenetic analysis: The BLAST analysis confirmed the sequence was from FlaB gene of Borrelia $s p$. from $R$. annulatus and $O$. savignyi. Thus, the $F l a B$ gene sequences generated from $R$. annulatus and $O$. savignyi isolates of Borrelia sp., were submitted to GenBank data base under the accession numbersMF084761 and MF084762, respectively. Analyses revealed that these sequences are nearly identical with more than $99 \%$ similarity with the cognate gene sequences of Egyptian Borre- lia $s p$. isolates from $R$. annulatus available in the database and share $99.2 \%$ nucleotide identity amongst them. The FlaB gene sequences of these Brazil Borrelia sp. isolates from $R$. microplus were found to have 99.2$97 \%$ nucleotide identity with $B$. theileri strain KAT from $R$. geigyi in Mali and Japan Borrelia sp. isolates from Haemaphysalis flava were found to have $95 \%$. They have also a very close phylogenetic relation with isolates from USA and Portugal (Fig. 3). Analyses revealed that these sequences are 
nearly identical with more than $99 \%$ similarity with the cognate gene sequences of Egyptian Borrelia sp. isolates from O. savignyi available in the database and share 99.1 $\%$ nucleotide identity amongst them. The $F l a B$ gene sequences of these Brazil Borrelia sp. isolates from $R$. microplus have 99.2, $97 \%$ nucleotide identity with Borrelia theileri strain KAT from $R$. geigyi in Mali and USA Borreliella burgdorferi were found to have $95 \%$. They have also a very close phy- logenetic relation with isolates from USA and Portugal (Fig.3). Thus, close genetic relatedness was observed between Borrelia sp. isolates from this region of Egypt with Brazil and Mali rather than its neighbouring country Japan. In that respect, this study on phylogenetic relation of Borrelia $s p$. of cattle and camels isolate of Salhia \& Shalatein regions with other isolates throughout the world may be considered first report from Egypt.

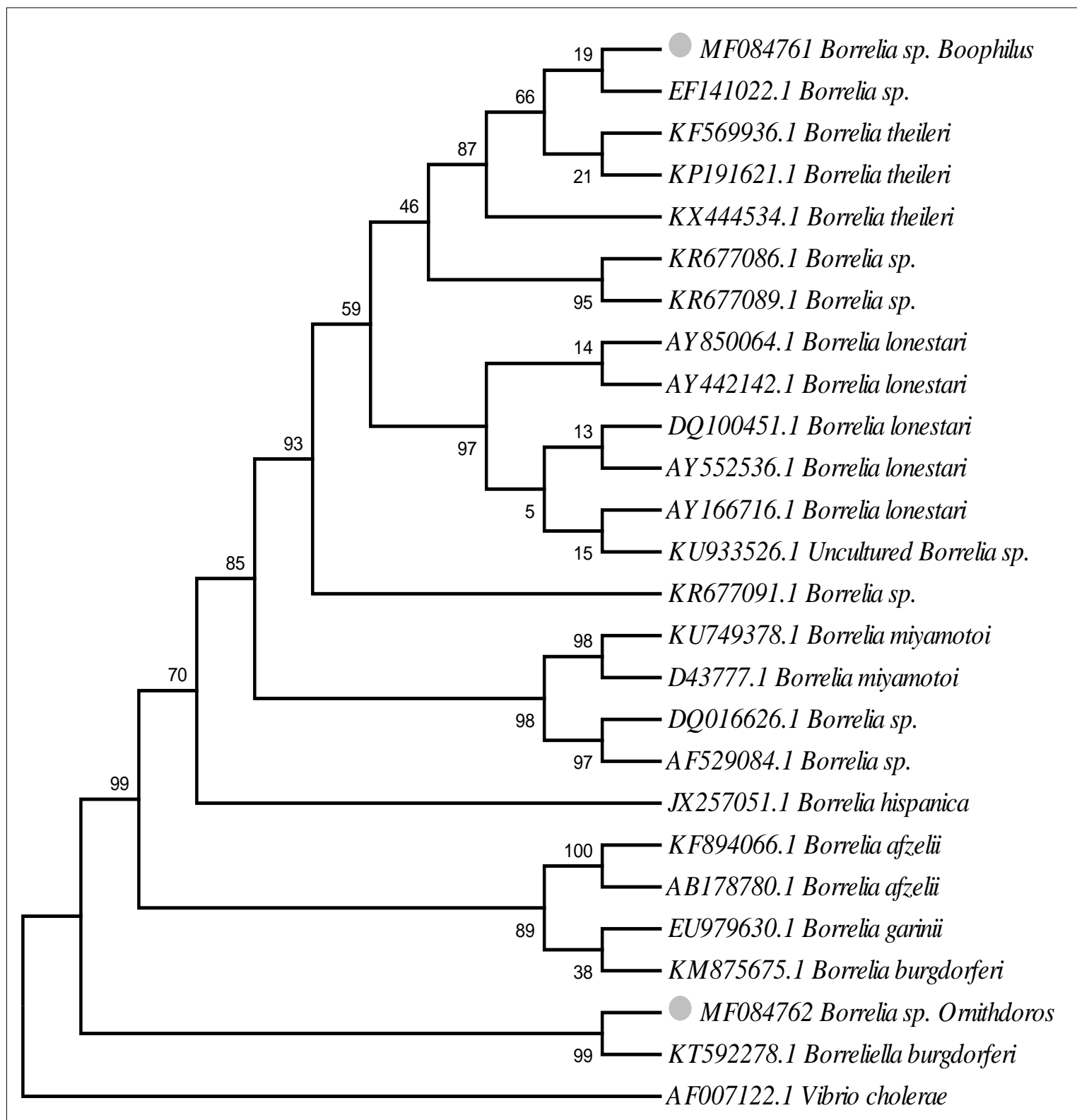

Fig. 3: Phylogenetic tree of Borrelia based on flaB gene. All sequences were aligned and Neighbor-joining tree was constructed. Upper black circle indicates to accession number of Borrelia sp. found in $R$. annulatus, lower black circle indicts to accession number of Borrelia sp. found in O. savignyi.

The BLAST analysis confirmed the sequence was from $18 S$ rRNA gene of $\mathrm{B}$. bi- gemina. Thus, the $18 S$ rRNA gene sequences generated from $R$. annulatus isolates of $B$. 
bigemina, were submitted to GenBank data base under accession number MF004418.

Analyses revealed that these RNA gene sequences of Egyptian B. bigemina isolates found to have $99.8 \%$ nucleotide identities with $B$. bigemina from Puerto Rico and Spain, and they also have a very close phylogenetic relation $99 \%$ with isolates from
Uganda, and very close phylogenetic relation $99 \%$ with isolates from China from $I x$ odes persulcatus ticks (Fig. 4). Thus, close genetic relatedness was observed between $B$. bigemina isolates from this region of Egypt with Puerto Rico and Spain rather than its neighbouring country China.

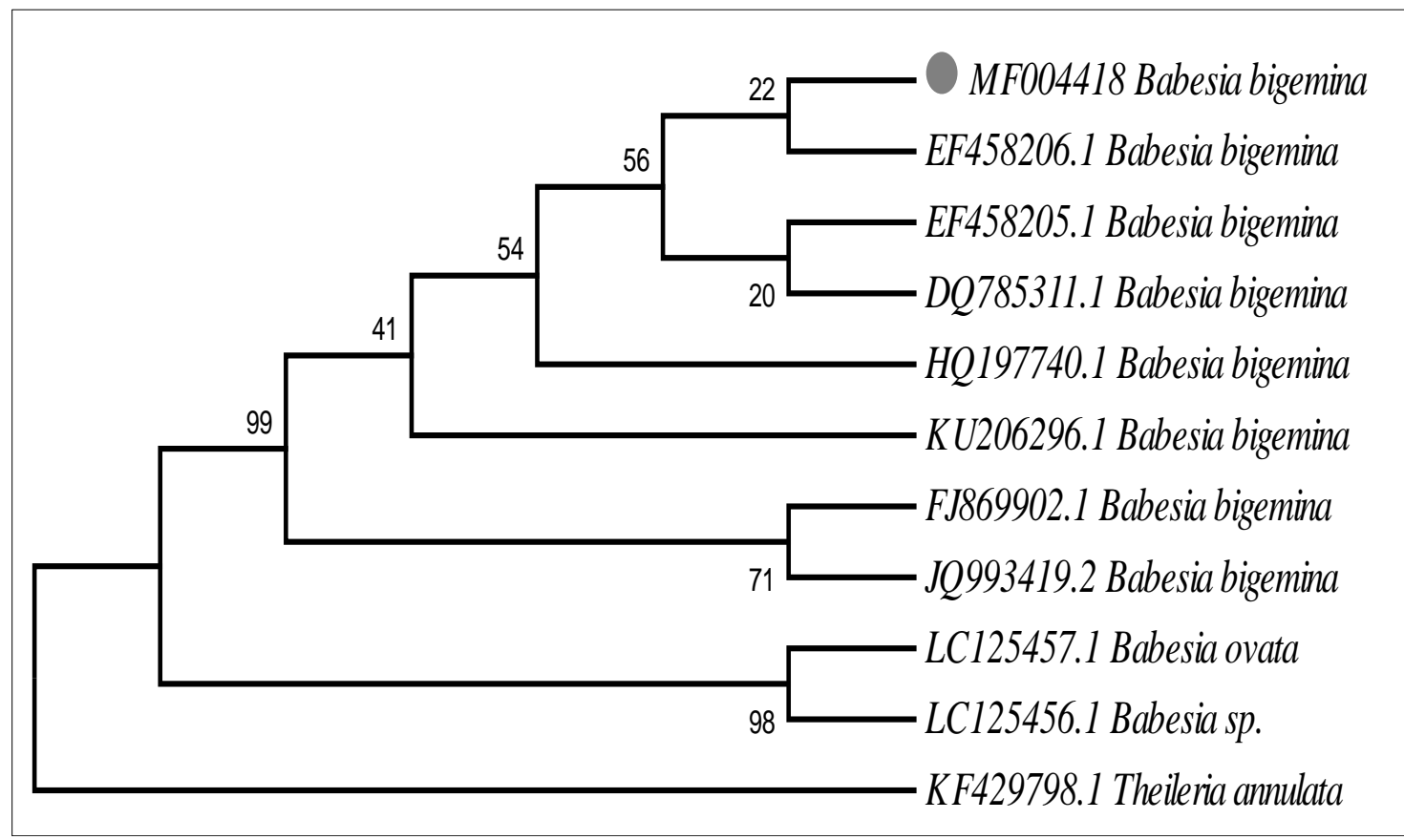

Fig. 4: Phylogenetic tree of Babesia based on $18 S$ rRNA gene. All sequences were aligned and Neighbor-joining tree was constructed. Black circle indicates to the accession number of Babesia bigemina that was found in $R$. annulatus.

\section{Discussion}

The most economic important of ticks is strongly due to their ability to acquire disease agents from infected hosts and transmit these agents to uninfected hosts that may be animals or humans. In this study, two tick species, one soft tick, O. savignyi and another hard tick, $R$. annulatus were chosen to determine their ability to serve as carriers for pathogens. It is well known that $O$ savignyi has a zoonotic important and a previous study done (Helmy, 2000) confirmed the presence of this tick species in Shalatein that locate at the southern boundary of Egypt. The main camel market in this town includes thousands of camels imported from Sudan and other African countries. The persons accompanied with camels may be bitted by an infected $O$. savignyi with pathogens such as Borrelia (Shanbaky and Helmy, 2000).
Thus, O. savignyi was investigated for the presence of Borrelia or other pathogens to achieve the goal of this study that concern the new genotype not isolated before from Egypt. On the other hand, the cattle tick, $R$. annulatus was the main tick on cattle in Egypt (El Kammah et al, 2001). Globally, the genus Rhipicephalus (formerly Boophilus) is the main vector of bovine borreliosis, such as Borrelia theileria (Yparraguirre et al, 2007, McCoy et al, 2014) and Babesia spp. to cattle (Adham et al, 2009). To fulfill this goal, $R$. annulatus was collected from Salhia and Banha and investigated for the presence of Borrelia and Babesia. Then the positive ticks were sequenced and the obtained sequences were analyzed to determine the new expected genotypes.

In Egypt, available data about the occurrence of Lyme disease are scarce and no 
studies documented the presence of Lyme borreliosis in Egyptian animals and tick carriers verifying its zoonotic evidence. Also, no trial to isolate $B$. burgdorferi from the clinical samples was done (Elhelw et al, 2014).

Human infection with $B$. persica is transmitted by the soft tick Ornithodoros tholozani and was reported from Iran, Israel, Egypt, India, and Central Asia (Baneth et al, 2016). In Egypt, few articles reported the existence of Lyme disease in humans and animals. Samir et al, (2015) confirmed the occurrence of $B$. burgdorferi infection in Egyptian dogs in which the only identified tick species is Rhipicephalus sanguineus. Borrelia sp., the causal organism of Lyme borreliosis.In the present study, 350bp fragment corresponding to Borrelia sp. was amplified from $R$. annulatus (5.8\%). Similar data were by Adham et al. (2010) who found that $8 \%$ out of $882 R$. annulatus ticks were infected with B. burgdorferi. There is a conflict between the identification of Borrelia in that finding and in this study because the present authors found that sequence of partial flab gene obtained from Borrelia sp. in $R$. annulatus (accession number: MF0847 61 ) is close to $B$. theleria (accession number: KF569936.1) and Borrelia sp (accession number: EF141022.1) without any correlation with $B$. burgdroferi. Dubinina et al, (2000) and Guiqing et al, (2003) found that of the 498 I. scapularis ticks collected from Rhode Island, Connecticut, New York, and New Jersey, 91 of 438 (20.7\%) nymphal ticks and 15 of $60(25.0 \%)$ adult ticks were positive by PCR assay, Daiva et al. (2004) using PCR found that $(6.9 \%)$ I. ricinus ticks were infected with $B$. burgdorferi. In the present study, a low infection rate $(1 \%)$ of Borrelia sp. was observed in both nymph and adult soft tick $O$. savignyi. The results agreed with Adhamet al, (2010) who found $B$. burgdorferi infected 1541 O. savignyi collected from Dahshour, Giza Governorate. In the present study, Borrelia in O. savignyi (accession number: MF084762) is very close to $B$. burgdorferi (accession number:
KT592278.1). Helmy (2000) recorded Borrelia $s p$. infection in $35.5 \%$ of $O$. savignyi collected from Dahshour, Giza Governorate. Shanbaky and Helmy (2000) found that Lyme borreliosis was a multiorgan infection caused by spirochetes of the B. burgdorferi, Borrelia garinii, and Borrelia afzelii, which are transmitted by ticks of the Ixodes species (Hengge et al, 2003). Disease burden within cattle is a concern around the world. The first observation of B. theileri in R.geigyiin Mali was related to and overlaps in distribution with $R$. decoloratus and $R$. annulatus, known vectors of $B$. theileri. However, minimal data exist on the infection rates in $B$. theileri tick vectors (Estrada-Peña et al, 2006).

Many studies used the 18S rRNA gene in diagnosis Babesia species in animal hosts (Laha et al, 2015; Byaruhanga et al, 2016; Elhaig et al, 2016; Silveira et al, 2016; Liu et al, 2017) or tick vectors (De Vos et al, 1994; Bock et al, 2004; Adham et al, 2009; Wesonga et al, 2010; Rar et al, 2014). In the present study, the positive $R$. annulatus hemolymph with vermiculate stages of Babesia was screened by PCR and sequenced. The sequence (accession number: MF0044 18) was $100 \%$ identical with Babesia bigemina (accession number: EF458206.1). The absence of $B$. bovis, could be related to $B$. bigemina that had the higher rate of infection in the female ticks collected from cows and greater parasite density in their blood and the lack of active immunity. The prevalence of $B$. bigemina in the current study $(1.16 \%)$ was lower than that reported previously by Ibrahim et al, (2013) and Mahmoud et al, (2015) they recorded $5.2 \%$ and $32.4 \%$, respectively, in different Governorates of Egypt. These regional differences in prevalence may be due to differences in husbandry, tick distribution, detection methods, and time of sampling in Egypt. While in Banha, Qalyoubia Governorate B. bigemina positive samples were absent. Differences in animal management explain the absence of B. bigemina positive samples in Qalyoubia 
Governorate as cattle in this Governorate are kept in small numbers, and well cared by their owners and being regularly treated with Diazinon compound that controls ticks (Ghosh and Nagar, 2014). In this study, the $18 S$ rRNA gene sequences of these Egyptian B. bigemina isolates found to have $100 \%$ nucleotide identities with $B$. bigemina from Puerto Rico and Spain, and they also have a very close phylogenetic relation $99 \%$ with isolates from Uganda, and very close phylogenetic relation $99 \%$ with isolates from China from Ixodes persulcatus ticks. So, close genetic relatedness was between $B$. bigemi$n a$ isolates from this region of Egypt with Puerto Rico and Spain rather than its neighbouring country China. In that respect, this study on phylogenetic relation of B. bigemi$n a$ of cattle isolate of Salhia region with other isolates throughout the world may be considered as the first report of its kind from Egypt.

The Babesia sp. detected by microscope was low but it might increase if PCR was used for all ticks. The infection rate, even if it is low in ticks it may be increased with the number of ticks in the field causing increase infection rate in animals where, $8.1 \%$ of cattle were infected with $B$. bovis in North Sinai Governorate (Mazyad, 2002), 11.5\% of cow were infected with Babesia bigemina in Port Said Governorate (El-Fayomy et al, 2013), and $8.15 \%$ of cattle were infected with Babesia spp. in Menoufia Governorate (Nayel et al, 2012).

\section{Conclusion}

The present study investigated tick hemolymphs of the soft tick $O$. savignyi and the hard tick $R$. annulatus by Light microscope. Spirochetes were found in the two tick species while the vermicule form of Babesia was found in $R$. annulatus only. Tick positive samples were screened by PCR using flab gene for Borrelia and I8S rRNA for Babesia. The PCR amplified Borrelia and Babesia at 350 and $450 \mathrm{bp}$, respectively. The obtained amplicons were sequenced and recorded in GenBank with accession number
MF084762, MF084761 and MF004418 for Borrelia sp. in $O$. savignyi, Borrelia sp. in $R$. annulatus and B. bigemina in $R$. annulatus, respectively. In general, the genotype of Borrelia sp. recorded in O. savignyi is very close to B. burgdroferi that causes Lyme disease in human. However, the genotype of Borrelia sp. recorded in $\mathrm{R}$. annulatus is close to $B$. theileri that causes a mild disease in animals. The genotype of Babesia found in $R$. annulatus was $100 \%$ identical with $B$. bigemina that recorded before.

\section{References}

Adham, FK, Abd-El-Samie, EM, Gabre, R, M, El. Hussein, H, 2009: Detection of tick blood parasites in Egypt using PCR assay IBabesia bovis and Babesia bigemina. Parasitol Res. 105, 3:721-30.

Adham, FK, Emtithal, M, Abd-El-Samie, EM, Refaat, M, Gabre, Hala, El. Hussein, 2010: Detection of tick blood parasites in Egypt using PCR assay ii- Borrelia burgdorfer isensulato. J. Egypt. Soc. Parasitol. 40, 3:553-64.

Almeria, J, Castella, D, Ferrer, A, Ortuño, A, Estrada-Peña, J, F, et al, 2001: Bovine piroplasms in Minorca (Balearic Islands, Spain): a comparison of PCR-based and light microscopy detection. Vet Parasitol. 99: 249-59.

Baneth, G, Nachum-Biala, Y, Halperin, T, Hershko, Y, Kleinerman, G, et al, 2016: Borrelia persica infection in dogs and cats: clinical manifestations, clinicopathological findings and genetic characterization. Parasit. Vectors 10, 91: 244-9.

Bock, R, Jackson, L, de Vos, A, Jorgensen, W, 2004: Babesiosis of cattle. Parasitology 129: 247-69.

Burgdorfer, Willy, 1970: Hemolymph test: A technique for detection of rickettsiae in ticks. Am. J. Trop. Med. Hyg. 19: 1010-14.

Byaruhanga, C, Collins, NE, Knobel, D, Chaisi, ME, Vorster, I, et al, 2016: Molecular investigation of tick-borne haemoparasite infections among transhumant zebu cattle in Karamoja Region, Uganda. Vet. Parasitol. 3-4: 27-35. Casjens, S, Palmer, N, Van Vugt, R, Huang, WM, Stevenson, B, et al, 2000: A bacterial genome in flux: the twelve linear and nine circular extra chromosomal DNAs in an infectious isolate of the Lyme disease spirochete Borrelia burgdorferi. Mol. Microbiol. 35:490-6. 
Daiva, A, Jurga, T, Ilona, V, Milda, M, 2004: The Prevalence of Borrelia Burgdorferi in Ixodes ricinusticks detected by PCR in Lithuania. Vet. Ir. Zootechnika 28:45-47.

De Vos, AJ, Potgieter, FT, 1994: Bovine babesiosis. In Coetzer JAW, Thomson GR, Tustin RC (eds) Infectious diseases of livestockwith special reference to southern Africa. Oxford University Press, Cape Town.

Dubinina, HV, Alekseev, A, Jensen, PM, Macrouchina, N, 2000: Daily activity of uninfected andBorrelia-infected Ixodes rici-nusticks (Acarina, Ixodidae): Lyme borreliosis risk evaluation for different time intervals. Ekol. 4:27-31. El-Bahnasawy, MM,Labib, NA, Abdel-Fattah, MA, Ibrahim, AMA, Morsy, TA, 2012: Louse and tick-bornerelapsing fevers. J. Egypt. Soc. Parasitol. 42, 3:625-38.

El-Bahnasawy, MM, Morsy, ATA, Ragab, IF, Khater, MKhA, Morsy, TA, 2015: Lyme disease: What heath care staff must know? Egyptian Military Medical Journal (EMMJ) 70, 2: 4050.

El Kammah, KM, Oyoun, LM, El kady, GA, Abdel-Shafy, S, S, 2001: Investigation of blood parasites in livestock infested with argasid and ixodid ticks in Egypt. J. Egypt. Soc. Parasitol. 31, 2: 365-71.

El-Fayomy, AO, Ghoneim, AM, Abu-Samak, OA, Khidr, AA, 2013: Contribution of Babesia to the Illness of cows in Port Said Governorate, Egypt. Glob. Vet. 11, 1:118-22.

Elhaig, MM, Selim, A, Mahmoud, MM, ElGayar, EK, 2016: Molecular confirmation of Trypanosoma evansi and Babesia bigemina in cattle from Lower Egypt. Pak. Vet. J. 36, 4:40914.

Elhelw, RA, El-Enbaawy, MI, Samir, A, 2014: Lyme borreliosis: A neglected zoonosis in Egypt. Acta Trop. 140:188-92.

Estrada-Peña, A, Bouattour, A, Camicas, JL, Guglielmone, A, Horak, I, et al, 2006: The known distribution and ecological preferences of the tick subgenus Boophilus (Acari: Ixodidae) in Africa and Latin America. Exp. Appl. Acarol. 38:219-35.

Ghosh, S, Nagar, G, 2014: Problem of ticks and tick-borne diseases in India with special emphasis on progress in-tick control research: A review. J. Vector Borne Dis. 51:259-70.

Guglielmone, AA, Gaido, AB, Aguirre, DA, Cafrune, MM, 1997: Some quantitative aspects of natural babesial infection in the haemolynph of Boophilusmicroplus engorged female ticks. Paraiste 4:337-41.

Guiqing, W, Livens, D, Brei, B, Hongyan, W, Falco, R, et al, 2003: Real-time PCR for simultaneous detection and quantification of Borrelia burgdorferi in field-collected Ixodes scapularis ticks from the Northeastern United States. App. Environ. Microbiol. 69:4561-5.

Haberberger, RL, Constantine, NT, Schwan, TG, Woody, JN, 1989: Lyme disease agent in Egypt? Trans. R. Soc. Trop. Med. Hyg. 83:55-6. Haitham, E, Raoult, D, Drancourt, M, 2013: Relapsing fever borreliae in Africa. Am. J. Trop. Med. Hyg. 89:288-92.

Hammoud, NA, Hegazy, IH, el-Sawy, EH, 1995: ELISA screening for Lyme disease in children with chronic arthritis. J. Egypt Soc. Parasitol. 25, 2:525-33.

Helmy, N, 2000: Seasonal abundance of Ornithodoros (O.) savignyi and prevalence of infection with Borrelia spirochetes in Egypt. J. Egypt Soc. Parasitol. 30, 3:607-19.

Hengge, UR, Tannapfel, AK, Tyring, SK, Erbel, R, Arendt, G, et al, 2003: Lyme borreliosis. Lancet Infect. Dis. 3:489-500.

Hilpertshauser, H, Peter, D, Manuela, S, Lise, G, Alexander, M, 2006: Babesia spp. identified by PCR in ticks collected from domestic and wild ruminants in Southern Switzerland. Appl. Environ. Microbiol. 72:6503-7.

Hoogstraal, H, 1956: African Ixodoidea. I. Ticks of the Sudan. 1101. United State Naval Medical Research Unit No. 3, Cairo.

Ibrahim, HM, Moumouni, PF, Mohammed, A, Geba, K, Sheir, SK, et al, 2013: Molecular and serological prevalence of Babesia bigemina and Babesia bovis in cattle and water buffalos under small-scale dairy farming in Beheira and Faiyum Governorates, Egypt. Vet. Parasitol. 198:187-92.

Krause, PJ, Fish, D, Narasimhan, S, Barbour, AG, 2015: Borrelia miyamotoi infection in nature and in humans. Clin. Microbiol. Infect. 7: 631-9.

Laha, R, Mondal, B, Biswas, SK, Chand, K, Das, M, 2015: Detection of Babesia bigemina infection in cattle from north-eastern India by polymerase chain reaction and its genetic relatedness with other isolates. Trop. Anim. Hlth. Prod. 47, 3:633-6.

Liu, J, Guan, G, Li, Y, Liu, A, Luo, J, Yin, H, 2017: A molecular survey of Babesia species and detection of a new Babesia species by DNA 
related to $B$. venatorum from White Yaks in Tianzhu, China. Front. Microbiol. 8:419-24.

Mahmoud, MS, Kandil, OM, Nasr, SM, Hendawy, SH, Habeeb, SM, et al, 2015: Serological and molecular diagnostic surveys combined with examining hematological profiles suggests increased levels of infection and hematological response of cattle to babesiosis infections compared to native buffaloes in Egypt. Parasit. Vectors 8:319-23.

Mazyad, SA, Khalaf, SA, 2002: Studies on Theileria and Babesia infecting live and slaughtered animals in Al Arish and El Hasanah, North Sinai Governorate, Egypt. J. Egypt. Soc. Parasitol. 32, 2:601-10.

McCoy, H, Brandi, N, Ousmane, G, Tom, M, Schwan, G, 2014: Detection of Borrelia theileri in Rhipicephalus geigyi from Mali. Ticks Tick Borne Dis. 5:401-3.

Nayel, MK, El-Dakhly, M, Aboulaila, M, Elsify, A, Hassan, H, et al, 2012: The use of different diagnostic tools for Babesia and Theileria parasites in cattle in Menofia, Egypt. Parasitol. Res. 111:1019-24.

Parola, P, Raoult, D, 2001: Ticks and tick-borne bacterial diseases in humans: an emerging infectious threat. Clin. Infect. Dis. 32:897-9.

Rar, V, A, Epikhina, TI, Suntsova, OV, Kozlova, IV, Lisak, OV, et al, 2014: Genetic variability of Babesia parasites in Haemaphysalis spp. and Ixodes persulcatus ticks in the Baikal region and Far East of Russia. Infect. Genet. Evol. 28:270-5.

Safdie, G, Farrah, IY, Yahia, R, Marva, E, Wilamowski, A, et al, 2010: Molecular characterization of Borrelia persica, the agent of tick borne relapsing fever in Israel and the Palestinian Authority. PLoS ONE 5, 11:14105.

Saitou, N, Nei, M, 1987: The neighborjoining method: A new method for sequences. J. Mol. Biol. 16:111-20.

Saleh, AM, Adam, SM, Abdel-Motagaly, AM E, Ibrahim, AMA, Morsy, TA, 2015: Human babesiosis: A general review with special reference to Egypt. J. Egypt. Soc. Parasitol. 45, 3: 493-510.

Samir, A, Fahmy, A, Essam, Hatem, M, Orabi, A, 2015: Occurrence of canine borreliosis in Egyptian dogs: A public health threat. Transl. Biomed. 6, 2:4-9.

Shanbaky, NM, Helmy, N, 2000: First record of natural infection with Borrelia in Ornithodoros (Ornithodoros) savignyi: Reservoir poten- tial \& specificity of the tick to Borrelia. J. Egypt. Soc. Parasitol. 30, 3:765-80.

Silveira, JAG, de Oliveira, CHS, Silvestre, B T, Albernaz, TT, Leite, RC, et al, 2016: Molecular assays reveal the presence of Theileria spp. and Babesia spp. in Asian water buffaloes (Bubalus bubalis, Linnaeus, 1758) in the Amazon re gion of Brazil. Ticks Tick-borne Dis. 7, 5:101723.

Smeenk, I, Kelly, PJ, Wray, K, Musuka, G, Trees, A, J, et al, 2000: Babesia bovis and B. bigemina DNA detected in cattle and ticks from Zimbabwe by polymerase chain reaction. J. S. Afr. Vet. Assoc. 71:21-4.

Steere, A, C, Malawista, S, E, Snydman, D, R, 1977: Lyme arthritis: an epidemic of oligo artecular arthritis in children and adults in three Connecticut communications. Arthritis Rheum. 20:7-17.

Tamura, K, Dudley, J, Nei, M, et al, 2007: MEGA5: Molecular Evolutionary Genetics Analysis (MEGA) software version 5. Mol. Biol. Evol. 24:1596-9.

Trape, J, F, Diatta, G, Arnathau, C, Bitam, I, Sarih, M, et al, 2013: The epidemiology and geo-graphic distribution of relapsing fever borreliosis in West and North Africa, with a review of the Ornithodoros erraticuscomplex (Acari: Ixodida). PLoS One 8:78473.

Vial, L, Diatta, G, Ba, EH, Bouganali, H, Durand, $P$, et al, 2006: Incidence of tickborne relapsing fever in West Africa: longitudinal study. Lancet 368:37-43.

Vial, HJ, Gorenflot, A, 2006: Chemotherapy against babesiosis. Vet. Parasitol. 138:147-60.

Walker, AR, Bouattour, A, Camicas, JL, et al, 2003: Ticks of domestic animals in Africa. Edinburgh, UK: Bioscience Reports.

Wesonga, FD, Kitala, PM, Gathuma, JM, Njenga, MJ, Ngumi, PN, 2010: An assessment of tick-borne diseases constraints to livestock production in a smallholder livestock production system in Machakos District, Kenya. LRRD, 22. Williamson, P, Peggy, M, Billingsley, GJ, Teltow, J, Seals, P, et al, 2010: Borrelia, Ehrlichia, and Rickettsia spp. in ticks removed from persons, Texas, USA. Emerg. Infect. Dis. 16:441-6. Yparraguirre, LA, Machado, E, Ullmann, AJ, Piesman, J, Zeidner, NS, et al, 2007: A hard tick relapsing fever group spirochete in a Brazilian Rhipicephalus (Boophilus) microplus. Vector Borne Zoonot. Dis. 7:717-21. 


\section{Explanation of figure}

Fig. 1: Tick hemolymph smears stained by Giemsa: A\&B)forms of Borrelia sp.in R. annulatus(black arrows), C)crowded forms of Borrelia sp.in O. savignyi, and D)vermicule stage of Babesia bigemina in R. annulatus (white arrow).

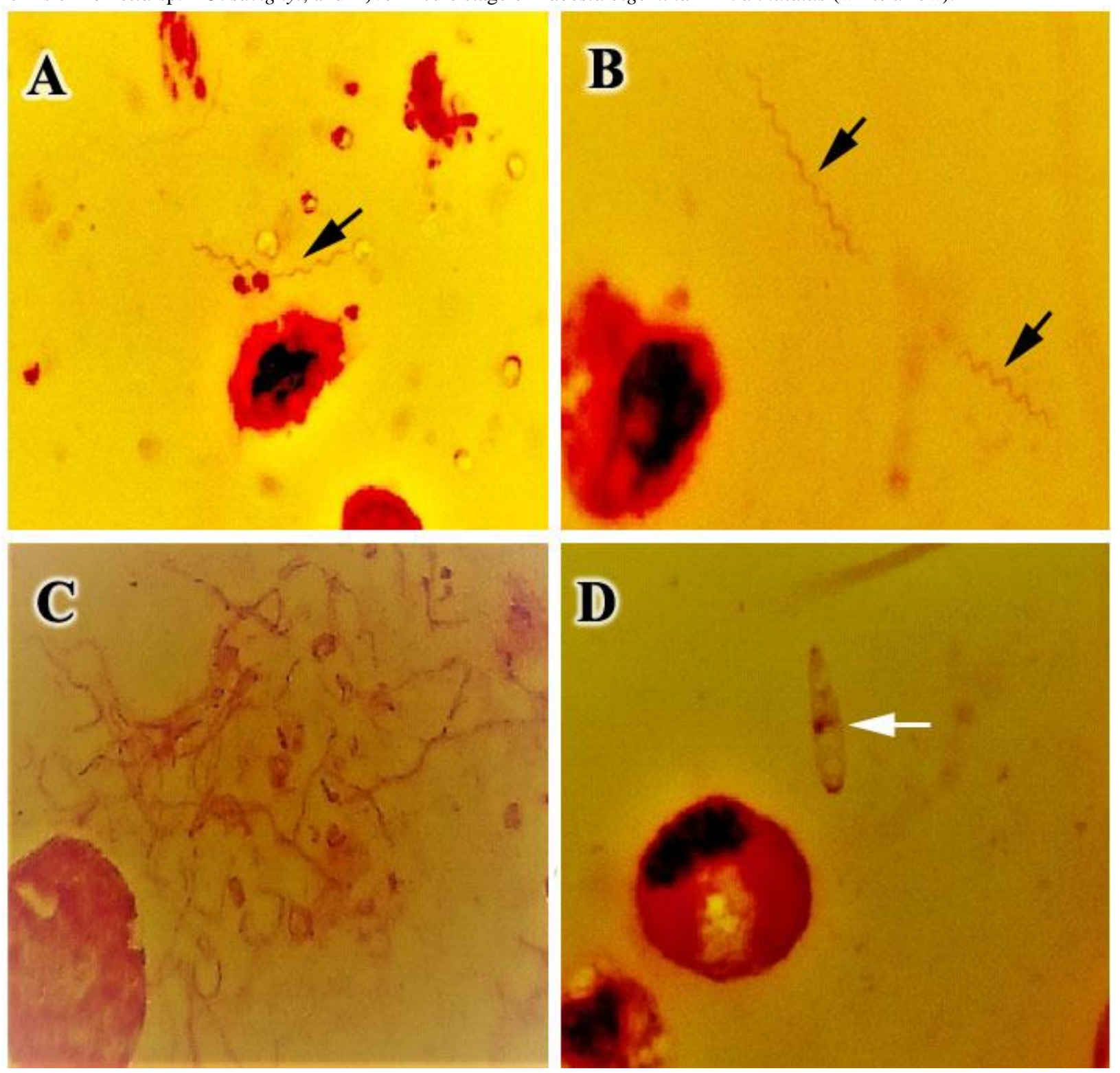

